\title{
Ecological indices of manufacture of Portland cement clinker and production of the dolomite clinker
}

\author{
Varvara Vinnichenko ${ }^{1,}{ }^{*}$, and Alexander Ryazanov ${ }^{2}$ \\ ${ }^{1}$ Kharkiv National University of Civil Engineering and Architecture, Department of Mechanization of \\ Construction Processes, Sumska st. 40, 61002 Kharkiv, Ukraine \\ ${ }^{2}$ Ufa State Petroleum Technological University, Department of Building Constructions, \\ Pervomayskaya st. 14, 450062 Ufa, Russia
}

\begin{abstract}
It is shown that the production of dolomite clinker in comparison with that of Portland cement is environmentally appropriate. When calcining dolomite for cementitious binder, the pollution of the atmosphere by carbon dioxide is reduced due to its isolation during decarbonization reactions of calcium carbonates. Reducing fuel consumption for clinker burning provides less carbon dioxide emissions from combustion products. Reducing the firing temperature creates obstacles to the formation of nitrogen oxides. The production of binders from dolomite in comparison with the production of Portland cement helps to protect the environment from contamination
\end{abstract}

\section{Introduction}

The main direction of industrial development is the reduction of energy costs for the production of products with a simultaneous decrease in the load on the environment. Dolomite rocks are one of the most widespread and insufficiently mastered by the construction industry varieties of mineral raw materials [1]. They can be used for the production of various types of binders and building materials based on them [2 -4]. One of the advantages of such binders is the significantly lower energy costs for firing, compared to the production of Portland cement [5].

\section{Results and discussion}

\subsection{Emissions of $\mathrm{CO}_{2}$ into the atmosphere from the raw mix}

Ecologists warn that if it is not possible to reduce the emission to the atmosphere of carbon dioxide, then our planet is waiting for a catastrophe [6], associated with an increase in temperature due to the so-called greenhouse effect. This phenomenon is explained by the

\footnotetext{
* Corresponding author: vvinnichenko@ukr.net
} 
fact that carbon dioxide gently slides the sun rays to the Earth, and the heat radiation from the Earth into the space complicates what constitutes the "greenhouse effect".

Carbon dioxide $\mathrm{CO}_{2}$ is released as a result of decomposition of chemical compounds of calcium and magnesium carbonates, which are part of mixtures for the production of cement clinker. When calcining dolomite for the production of a cement dolomitic binder, the main firing products are magnesium oxide $\mathrm{MgO}$, carbon dioxide $\mathrm{CO}_{2}$ and calcium carbonate $\mathrm{CaCO}_{3}$. Decarbonization of calcium carbonate is not carried out, since the firing temperature is kept below the start of the decomposition of $\mathrm{CaCO}_{3}$. The process proceeds according to the reaction [5]:

$$
\mathrm{CaMg}\left(\mathrm{CO}_{3}\right)_{2}=\mathrm{CaCO}_{3}+\mathrm{MgO}+\mathrm{CO}_{2}
$$

When roasting Portland cement raw meal, calcium and magnesium carbonates dissociate completely to form calcium oxide, magnesium oxide and carbon dioxide by reactions

$$
\begin{gathered}
\mathrm{CaCO}_{3}=\mathrm{CaO}+\mathrm{CO}_{2} \\
\mathrm{MgCO}_{3}=\mathrm{MgO}+\mathrm{CO}_{2}
\end{gathered}
$$

When calcining dolomite by reaction (1), carbon dioxide is released only as a result of the reaction (3) of the decarbonization of magnesium carbonate. The burning of Portland cement clinker is accompanied by the release of carbon dioxide from decomposition of calcium carbonate and magnesium carbonate according to reactions (2) and (3). The yield of chemically bound carbon dioxide from magnesium carbonate and calcium of raw materials per 1 ton of clinker is determined by the formula [7]:

$$
G_{\mathrm{CO}_{2}}=\frac{G_{c}^{T} \cdot \mathrm{MgO} \cdot M_{\mathrm{CO}_{2}}}{M_{\mathrm{MgO}} \cdot 100}+\frac{G_{c}^{T} \cdot \mathrm{CaO} \cdot M_{\mathrm{CO}_{2}}}{M_{\mathrm{CaO}} \cdot 100},
$$

where $G_{C}^{T}$ - the theoretical consumption of dry raw materials, $\mathrm{t}$;

$M_{\mathrm{CO} 2} M_{\mathrm{MgO}} M_{\mathrm{CaO}}$ - the molecular weight of carbon dioxide, magnesium oxide and calcium, respectively, t;

$\mathrm{MgO}, \mathrm{CaO}$ - the content of magnesium oxide and calcium in the feed mixture, $\%$.

Table 1 presents the chemical composition of the dolomite dropping of Dokuchaevsk Flux and Dolomite plant and the raw mix of cement clinker according to [8]. As follows from Table 1, the content of calcium and magnesium oxides in the cement raw meal is higher than in the dolomite. If we compare the release of carbon dioxide from a Portland cement raw meal $-0.565 \mathrm{t} / \mathrm{t}$ of clinker [7] and dolomite $-0.340 \mathrm{t} / \mathrm{t}$ of clinker, then the reduction in $\mathrm{CO}_{2}$ output from the material during calcination of dolomite will be $60 \%$.

Captions should be typed in 9-point Times. They should be centred above the tables and flush left beneath the figures.

Table 1. Chemical composition of raw mix

\begin{tabular}{|l|c|c|c|c|c|c|c|c|}
\hline Material type & LOI & $\mathbf{S i O}_{2}$ & $\mathbf{F e}_{\mathbf{2}} \mathbf{O}_{\mathbf{3}}$ & $\mathbf{A l}_{\mathbf{2}} \mathbf{O}_{\mathbf{3}}$ & $\mathbf{C a O}$ & $\mathbf{M g O}$ & Other & $\sum$ \\
\hline Dolomite & 45.92 & 2.15 & 0.60 & 0.52 & 29.83 & 20.53 & 0.45 & 100 \\
\hline $\begin{array}{l}\text { The raw mix } \\
\text { of cement } \\
\text { clinker }\end{array}$ & 38.00 & 12.92 & 1.13 & 3.09 & 66.19 & 1.41 & 0.09 & 100 \\
\hline
\end{tabular}




\subsection{Emissions of $\mathrm{CO}_{2}$ into the atmosphere as a result of combustion of fuel}

Theoretical costs of thermal energy for the formation of dolomite clinker represent the cost of heat for the dissociation of $\mathrm{MgCO}_{3}$, a certain amount of $\mathrm{CaCO}_{3}$, and also the dehydration of impurities [5]:

$$
q_{k l}=G_{\mathrm{CaCO}_{3}}^{C} \cdot\left(\Delta H_{t}\right)_{1}+G_{\mathrm{MgCO}_{3}}^{C} \cdot\left(\Delta H_{t}\right)_{2}+G_{A S_{2} \mathrm{H}_{2}}^{C} \cdot\left(\Delta H_{t}\right)_{3},
$$

where $G_{\mathrm{CaCO}_{3}}^{\mathrm{C}}, G_{\mathrm{MgCO}_{3}}^{\mathrm{C}}, G_{\mathrm{AS}_{2} \mathrm{H}_{2}}^{\mathrm{C}}$ - the content of calcium carbonate, magnesium carbonate and aluminosilicates in the dolomite per $1 \mathrm{~kg}$ of clinker, respectively;

$\left(\Delta H_{t}\right)_{1},\left(\Delta H_{t}\right)_{2},\left(\Delta H_{t}\right)_{3}$ - the enthalpy of decarbonization reactions of calcium carbonate, magnesium carbonate, aluminosilicate impurity, respectively.

Calculated by this formula, the value of the theoretical cost of heat energy for the firing of dolomite, which is presented in Table 1, is $225 \mathrm{kcal} / \mathrm{kg}$ of clinker. For comparison, the theoretical heat consumption for sintering the Portland clinker of Kramatorsk Cement Plant is $425 \mathrm{kcal} / \mathrm{kg}$ of clinker. The actual fuel consumption for firing depends on the moisture content of the raw material and the coefficient of efficiency of the thermal unit. In other words, if the initial moisture content of the raw mix and the efficiency of the furnace are equal, the fuel consumption for calcining the dolomite clinker is $47 \%$ lower compared to the Portland cement clinker. During the fuel combustion most of the carbon is converted to carbon dioxide. The formation of $\mathrm{CO}_{2}$ is directly proportional to the amount of fuel burnt, so the emission of carbon dioxide into the atmosphere during the combustion of fuel will be reduced. Therefore, the production of dolomite clinker in comparison with the production of Portland cement clinker represents a lower environmental risk for the environment in terms of carbon dioxide emissions.

We conducted experimental studies of dolomite clinker and cement $[8,9,10]$. The studies identified rational firing temperature and characteristics of the resulting material. The firing temperature is $700-780{ }^{\circ} \mathrm{C}$. The samples were formed in two ways: with sand (cement in a ratio of 1:3) and without sand. The closure was carried out with a solution of magnesium chloride six-water diluted with water to a density of $1.2 \mathrm{~g} / \mathrm{cm}^{3}$. When using a mixture of sand the compressive strength of the samples was $22.5 \mathrm{MPa}$ in 28 days. The compressive strength of the samples after 28 days of hardening obtained by molding without sand was $59.5 \mathrm{MPa}$. The results of physico-mechanical tests are presented in Table 2.

Table 2. The results of physical and mechanical tests

\begin{tabular}{|c|c|c|c|c|c|c|c|c|c|c|}
\hline \multirow{2}{*}{ 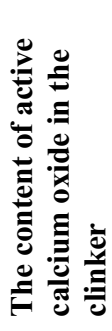 } & \multirow{2}{*}{$\begin{array}{l}\begin{array}{l}\text { Sieve } \\
\text { residue }\end{array} \\
\text { N008 }\end{array}$} & \multirow[b]{2}{*}{ 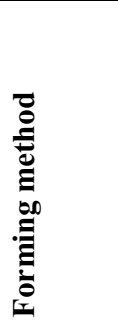 } & \multirow[b]{2}{*}{$\frac{U}{3}$} & \multicolumn{2}{|c|}{$\begin{array}{l}\text { Setting time } \\
\text { the hour/min }\end{array}$} & \multicolumn{5}{|c|}{$\begin{array}{l}\text { The limit of compressive strength } \\
\text { (MPa) in terms }\end{array}$} \\
\hline & & & & 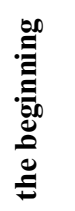 & $\begin{array}{l}\Xi \\
\Xi \\
\Xi\end{array}$ & 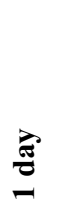 & 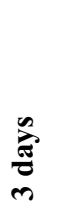 & $\underset{n}{\stackrel{\sigma}{\sigma}}$ & 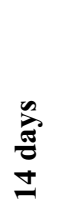 & 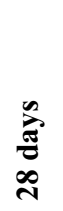 \\
\hline $\begin{array}{l}\mathrm{CaO}_{\mathrm{a}^{-}} \\
0.61\end{array}$ & 9.3 & $\begin{array}{l}1: 3 \text { with } \\
\text { sand }\end{array}$ & 0.42 & & & 6.5 & 11.0 & 13.5 & 18.0 & 22.5 \\
\hline $\begin{array}{l}\mathrm{CaO}_{\mathrm{a}^{-}} \\
0.61\end{array}$ & 9.3 & $\begin{array}{l}\text { the } \\
\text { dough }\end{array}$ & 0.30 & 0.45 & 2.35 & 18.8 & 25.0 & 43.8 & 50.0 & 59.5 \\
\hline
\end{tabular}




\subsection{Formation of nitrogen oxides}

Combustion of organic fuels leads to the formation of mainly combustion products in the form of carbon dioxide, water vapor, sulfur oxides (when using solid and liquid fuels) and nitrogen oxides. The most toxic emissions of nitrogen oxides cause the primary need to reduce their emissions into the atmosphere. The amount of nitrogen oxides formed determines the combustion conditions of fuels. Factors affecting the formation of NOx: temperature of the flare in the combustion chamber, residence time of the gas in the hightemperature zone, concentration of oxygen and nitrogen in the combustion zone, temperature of heating of the air intended for fuel burning. The greatest influence on the amount of oxides $N O x$ produced is exerted by the temperature at which combustion occurs. According to the American Petroleum Institute [11] formation of NOx at a flame temperature of $1900{ }^{\circ} \mathrm{C}$ is twice as high compared to formation at a temperature of 1300 ${ }^{\circ} \mathrm{C}$. The temperature of the material during calcination of dolomite is within an interval of about $750-780{ }^{\circ} \mathrm{C}$, and in the production of Portland cement clinker it is $1330-1360{ }^{\circ} \mathrm{C}$. The combustion temperature of the fuel in rotary kilns exceeds the material temperature by 300 $400^{\circ} \mathrm{C}$. Analyzing these figures, we can conclude that when calcining dolomite, the reduction in the firing temperature will help to reduce the presence of toxic nitrogen oxides in combustion products.

\section{Conclusions}

It is shown that the production of dolomite clinker in comparison with that of Portland cement is ecologically reasonable:

- the pollution of the atmosphere with greenhouse generated carbon oxides decreases by more than $60 \%$,

- the calcination temperature of dolomite clinker is lower by $420^{\circ} \mathrm{C}-580^{\circ} \mathrm{C}$ compared to

Portland cement, which worsens the conditions for the formation of toxic nitrogen oxides.

\section{References}

1. V. Zyrjanova, G. Berdov, N. Tjuleneva. Current problems in construction and architecture, 189 (2007)

2. G. Shabanova, Proc. scientific. works UkrSART, 138, 148-154 (2013)

3. C. Mazuranic, J. Amer. Ceram. Soc. 65 (10), 523-526 (1982)

4. S. Sorel, US Patent Office, Patent 53/092 (1866)

5. A. Volzhenskij, Mineral'nye vjazhushhie veshhestva (Moscow, Stroyizdat, 1986)

6. Climate Change. The Physical Science Basis (2013)

7. H. Vorobyov, D. Mazurov, Thermotechnical calculations of cement kilns and apparatus, 134, (Moscow, 1962)

8. V. Vinnichenko, A. Ryazanov, Ecology and industry, 2, 111 (2013)

9. A. Plugin, V.Vinnichenko, O. Borzjak, Proc. scientific. works UkrSART, 143, 87-97 (2014)

10. A. Ryazanov, V. Vinnichenko, A. Plugin, Proc. scientific. works UkrSART, 138, 7785 (2013)

11. Burners for Fired Heaters in General Refinery Services, 12 (1995) 